DOI: $10.46340 /$ eppd.2020.7.6.20

Nataliia Karpinska, PhD in Law

ORCID ID: https://orcid.org/ 0000-0001-9658-3623

Lesya Ukrainka Volyn National University, Ukraine

\title{
AGRICULTURAL LEGAL NATURE OF RELATIONS APPLICATION OF SANITARY AND PHYTOSANITARY MEASURES (SPM)
}

\author{
Наталія Карпінська, к. ю. н. \\ Волинський національний університет імені Лесі Українки, Україна

\section{АГРАРНО-ПРАВОВА ПРИРОДА ВІДНОСИН ЗАСТОСУВАННЯ САНІТАРНИХ ТА ФІТОСАНІТАРНИХ ЗАХОДІВ (СФЗ)}

The article is devoted to the analysis of the legal nature of the relationship between the application of sanitary and phytosanitary measures. Pointing out that the legal relations of the SPM form a whole set of heterogeneous social relations governed by the legal norms of various branches of law, the author, while distinguishing components (agrarian law, environmental law, administrative law and international law), highlights the agrarian law component as basic one. The agrarian law component of the SPM application is basic, as these legal relations arise as a result of agricultural activity, given its anthropogenic impact on nature, to meet the needs of farmers and to protect against the negative consequences of such impact.

Particular attention is paid to the agroprotective conceptual approach in modern agrarian law doctrine, that was little-studied in legal science yet. Also, in the article, the author distinguishes SPM from a related category - from technical barriers.

Keywords: sanitary and phytosanitary measures, legal nature, agrarian-legal nature, WTO, EU.

Постановка проблеми. Сьогодні особливого значення набуває розвиток науки аграрного права України, яка шляхом розробки теоретичних рекомендацій покликана сприяти забезпеченню найбільш ефективного правового регулювання суспільних відносин в аграрному секторі економіки ${ }^{1}$. Однак, значний потенціал аграрно-правової науки залишається практично незадіяним для грунтовного дослідження правових проблем застосування санітарних та фітосанітарних заходів (далі - СФЗ) у контексті вимог СОТ та ЄС. Це призводить, зокрема, до появи багатьох «пробілів» у теорії правового регулювання застосування СФЗ. Перш за все, такою білою плямою слід визнати питання визначення юридичної природи відносин застосування СФЗ. 3 однієї сторони - правовідносини застосування СФЗ формують собою цілий комплекс неоднорідних суспільних відносин, врегульованих правовими нормами різних галузей права, тому можна виокремити кілька складових їхньої юридичної природи: аграрно-правову, еколого-правову, адміністративно-правову, міжнародно-правову, з іншої - питання застосування СФЗ досліджувалося здебільшого в науці екологічного права в контексті збереження права на екологічну безпеку й сприятливе навколишнє природне середовище ${ }^{2}$, але не були предметом комплексного наукового дослідження.

Стан дослідження. Юридична природа відносин застосування СФЗ неоднозначна та у зв'язку 3 цим досить дискусійна. Оскільки це досить значний пласт неоднорідних суспільних відносин, їх правова ідентифікація вимагає уважного наукового аналізу. Зокрема, важливим є доробок А. В. Духневича, який грунтовно опрацював на дисертаційному рівні проблематику реалізації Угоди СОТ про сільське господарство, торкнувшись правових питань застосування СФ ${ }^{3}$. На рівні

\footnotetext{
${ }^{1}$ Багай, Н. О. (2002). Розвиток науки аграрного права України: автореферат дисертації на здобуття наукового ступеня кандидата юридичних наук. Київ: Установа: Інститут держави і права імені В. М. Корецького, 1-19. 2 Духневич, А. В. (2016). Правові проблеми реалізації Угоди про сільське господарство СОТ в Україні. Київ, 230-231.

3 Духневич, А. В. (2017). Організаційно-правове забезпечення реалізації угод Світової організації торгівлі у сільському господарстві Украӥни. Київ, 210-389.
} 
кандидатської дисертації деякі аспекти застосування СФЗ розглянула Л. І. Полюхович, дослідження якої має назву «Організаційно-правові питання виробництва, переробки та реалізації сільськогосподарської продукції у контексті вимог СОТ» ${ }^{1}$. Важливі засадничі ідеї методології правового регулювання аграрних відносин у контексті вступу до СОТ та асоціації з СС висловлені B. I. Семчиком у циклі праць ученого ${ }^{2}$. Досліджувана проблема продовжує бути актуальною та потребує фахової розвідки з точки зору розробки та закріплення правових положень в чинному національному законодавстві ${ }^{3}$.

Виклад основного матеріалу. Теорія аграрного права розуміє аграрні правовідносини як врегульований нормами права (аграрного та інших галузей) комплекс суспільних відносин, що виникають між сільськогосподарськими товаровиробниками (суб'єктами аграрного господарювання), з одного боку, та іншими видами господарюючих суб'єктів, членами сільськогосподарських підприємств і їх найманими працівниками, органами державної влади й органами місцевого самоврядування, $з$ другого, з приводу конкретних об' єктів (майна, земель, праці тощо) на підставі певних юридичних фактів і які надають їх учасникам взаємозумовлені права й обов'язки у сфері сільськогосподарської й пов'язаної з нею діяльності ${ }^{4}$. Відносини застосування СФЗ у сільському господарстві мають яскраво виражену аграрно-правову природу, що добре простежується під час аналізу їх складу:

- об'єктами таких відносин є: сільськогосподарська продукція; сільськогосподарські рослини і тварини; способи й технології виробництва і переробки сільськогосподарської продукції;

- суб'єктами цих відносин є: виробники сільськогосподарської продукції, уповноважені органи державної влади, іноземні держави;

- зміст цих відносин складають права та обов'язків суб'єктів, спрямовані на дотримання санітарних та фітосанітарних вимог під час здійснення сільськогосподарської діяльності 3 метою захисту життя і здоров'я рослин, тварин, людей, а також недопущення або мінімізації іншої можливої шкоди.

Досліджуючи специфіку відносин застосування СФЗ у сільському господарстві, можна виокремити два основні концептуально-правові підходи до визначення їх аграрно-правової природи: виробничо-господарський та агропротекційний.

У рамках виробничо-господарського підходи відносини застосування СФЗ розглядаються як невід'ємна частина сільськогосподарського виробництва. Справді, сільськогосподарська діяльність у всіх своїх різноманітних проявах безпосередньо пов'язана із СФЗ, залежить від них та обмежується ними. Застосування СФЗ має надзвичайно важливе значення для сучасного сільського господарства, адже виконує три основні функції:

- економічну (зменшення витрат, збільшення доходів і продуктивності. Сучасне ефективне господарювання в галузі рослинництва неможливе без захисту рослин, який дозволяє скоротити колосальні втрати, зокрема, сільськогосподарської продукції від шкідників та хвороб ${ }^{5}$; так само ефективність та продуктивність тваринництва залежить від вчасних, обгрунтованих та збалансованих СФЗ);

- екологічно-превентивну (захист дикої флори і фауни від ризиків, що супроводжують сільськогосподарську діяльність та можуть негативно вплинути на їх існування. Зокрема, значну загрозу для рослинного світу створює розповсюдження шкідників та хвороб рослин, яке може завдати значної шкоди не тільки навколишньому середовищу в цілому, а й життю та здоров'ю людини 6 );

\footnotetext{
${ }^{1}$ Полюхович, Л. І. (2014) Організаційно-правові питання виробництва, переробки та реалізації сільськогосподарської продукції у контексті вимог СОТ: автореферат дисертації на здобуття наукового ступеня кандидата юридичних наук. Харків: Національний юридичний університет ім. Ярослава Мудрого, 1-18.

${ }^{2}$ Семчик, В. I .(2005). Організаційно-правові проблеми вступу України до СОТ і Європейського Союзу та участі у формуванні єдиного економічного простору. Правова держава, 16, 325 - 334.

${ }^{3}$ Боснюк-Григор'єва, Ю. (2017). Україна на шляху до європейських стандартів у сфері санітарних та фітосанітарних заходів: що зроблено та які виклики слід подолати. Історико-правовий часопис, 2 (10), 170-175.

${ }^{4}$ Уркевич, В. Ю. (2007). Аграрні правовідносини в Україні: автореферат дисертації на здобуття наукового ступеня доктора юридичнх наук. Харків: Національний юридичний університет ім. Ярослава Мудрого, 1-39.

${ }^{5}$ Курзова, В. В. (2009). Еколого-правове регулювання карантину рослин: автореферат дисертації на здобуття наукового ступеня кандидата юридичних наук. Київ: НУ біоресурсів і природокористування України, 1-20.

${ }^{6}$ Там само.
} 
- екологічно-відновлюючу (у випадку розповсюдження шкідників чи хвороб серед сільськогосподарських рослин чи тварин СФЗ набувають інших форм та способів, а також можуть переходити із превентивного режиму до карантинного з метою припинення негативних наслідків реалізації екологічних ризиків, відновлення стану екологічної безпеки тощо).

Отже, відносини застосування СФЗ є невід'ємною складовою сучасної сільськогосподарської діяльності, а значить i- частиною сучасного аграрного права. Незважаючи на цей органічний взаємозв'язок, відносини застосування СФЗ досі не вивчалися як повноцінна і об'ємна складова предмету аграрного права України. Це не можна пояснити популярними, але поверховими аргументами щодо «стагнації» аграрно-правової науки, її консерватизмом чи іншими негативними явищами. Насправді, наука аграрного права України є досить динамічною. В аграрно-правових дослідженнях учені постійно наводять підтвердження невпинного розвитку та еволюції сучасного аграрного права та ретроспективи його становлення (Н. О. Багай ${ }^{1}$, I. М. Заріцька ${ }^{2}$, I. В. Духневич ${ }^{3}$, М. М. Чабаненко ${ }^{4}$, Т. О. Коваленко ${ }^{5}$ ), тощо. Розвиток аграрного права $є$ безцінним надбанням вітчизняної правової культури та стратегічно важливим напрямом подальшої еволюції правової системи України. 3 цього приводу В. В. Носік вдало підкреслює, що за своїм функціональним призначення аграрне право України виступає універсальним соціальним регулятором, який має забезпечувати утвердження у суспільстві таких соціальних цінностей як людина, іiї життя і здоров'я, свобода, справедливість, рівність особи у всіх сферах людського життя незалежної, демократичної, правової держави ${ }^{6}$. Аграрне право - стратегічно важлива галузь права, норми якої регулюють відносини, які виникають у процесі виробництва, переробки, зберігання, транспортування та реалізації сільськогосподарської продукції, кількість і якість якої впливає на продовольчу безпеку країни і розвиток економіки в цілому ${ }^{7}$. Саме тому адекватність аграрного права фактичним суспільним відносинам, суспільним потребам має величезне, стратегічне значення для України.

Інші грані аграрних правовідносин підкреслює Т. О. Коваленко, яка вважає, що аграрне право набуває все більшого значення в сучасних умовах необхідності гарантування продовольчої безпеки держави.. переорієнтації основних напрямків експорту сільськогосподарської продукції, проведення адаптації національного аграрного законодавства до вимог $\mathrm{CC}$, особливо в частині забезпечення якості та безпечності сільськогосподарської продукції̈. Подібну думку висловив і А. М. Статівка, який стверджує, що за умов інтеграційних процесів аграрне право знаходиться на етапі трансформаційних змін через оновлення нормативно-правової бази, виникнення нових напрямів правового регулювання, появу нових правових інститутів тощо. Важливе місце серед відносин, які належать до предмета правового регулювання аграрного права посідають відносини усфері правового забезпечення якості та безпечності сільськогосподарської продукції'.

Національна доктрина аграрного права визнає відносини усфері дотримання якості сільськогосподарської продукції частиною предмета аграрного права, 3 огляду на те, що вони $\epsilon$

\footnotetext{
${ }^{1}$ Багай, Н. О. (2017). Наукові підходи до періодизації розвитку аграрного законодавства. Правові проблеми державно-приватного партнерста в умовах євроінтегращії: матеріали міжнародного конгресу (2-4 червня 2017 р., м. Одеса), 84-86.

${ }^{2}$ Єрмоленко, В. М. Гафурова, О. В. Гребенюк, М. В. (2010). Аграрне право України. Київ, 608.

3 Духневич, I. В. (2011). Розвиток аграрного законодавства Украӥни. Київ, 264.

4 Чабаненко, М. М. (2015). Система аграрного права України: методологічні засади становлення та розвитку. Київ, 437.

${ }^{5}$ Коваленко, Т. О. (2015). Об'єктивні умови формування аграрного права України. Історико-правовий часопис, $1(5), 80-85$.

${ }^{6}$ Носік, В. В. (2010). Аграрні права та їх юридична природа в сучасних умовах. Актуальні проблеми реформування земельних, екологічних, аграрних та господарських правовідносин в Україні: збірник наукових праць науково-практичної конферениї (14-15 травня 2010 р., м. Хмельницький), 122-123

${ }^{7}$ Корнієнко, Г. С. (2018). Аграрне право як стратегічна галузь права. Пріоритетні напрями розвитку аграрного законодавства і права в сучасних умовах: матеріали конференції (20 квітня 2018 р., м. Харків), $77-81$.

${ }^{8}$ Коваленко, Т. О. (2015). Передумови формування аграрного права України. Сучасні тенденції та перспективи розвитку аграрного, земельного і екологічного права: матеріали конференції. (22-23 травня 2015 р., м. Київ), 44-47.

${ }_{9}^{9}$ Статівка, А. М. (2017). Сучасне аграрне право в контексті євроінтеграційних процесів. Сучасний стан та перспективи розвитку екологічного, земельного та аграрного права в умовах євроінтеграції: матеріали круглого столу (8 грудня 2017 р., м. Харків), 94-98.
} 
органічною складовою загальної системи відносин щодо виробництва сільськогосподарської продукції. При цьому саме якість виробленої продукції визначає більшість потенційних можливостей іiі подальшого руху на ринку'.

У цілому, можна погодитися із думкою Л. І. Купчені, яка доходить висновку про те, що аграрне право продовжує виконувати притаманні йому регулятивну, охоронну та виховну (превентивну) функції, однак сучасні міжнародні тенденції (вимога сталого розвитку сільського господарства, вектори розвитку СОТ та СС) наповнюють ці функції новим змістом ${ }^{2}$. А. М. Статівка йде ще далі та говорить про те, що тенденції сучасного аграрного виробництва в умовах інтеграційних процесів $€$ фактором розширення і підставою змістовного наповнення відносин за участю національних сільськогосподарських товаровиробників, які вказують на їх особливості. Зокрема, мова йде про агронанотехнологічні, агроінвестиційні, агроінформаційні, агромаркетингові та інші відносини, які розширюють предмет правового регулювання аграрного права ${ }^{3}$.

Якщо спробувати визначити місце правового регулювання СФЗ у системі сучасного аграрного права, то відповідь на це питання $\epsilon$ неоднозначною. Справа у тому, що традиційно аграрно-правова наукова спільнота узагальнювала цей пласт правовідносин під загальними маскуючими категоріями «екологізації аграрного виробництва», «технологічні вимоги до здійснення виробничо-господарської діяльності», «агроінновації» тощо. У зв'язку з цим, відносинам у сфері застосування СФЗ присвоєно ярлик певної «технічності», своєрідної вторинності порівняно із іншими різновидами аграрних відносин. Цим можна пояснити такий розрив між величезною кількістю наукових праць, присвячених правовим питанням екологізації сільськогосподарської діяльності, та мізерним числом публікацій, спрямованих на спеціальне дослідження СФЗ як безпосереднього втілення екологізаційних тенденцій в аграрному виробництві.

Подібна проблема склалася і з правовим регулюванням СФЗ, яке виявилося дещо розмитим у аграрному законодавстві, що спричинене відсутністю чітко централізованої системи нормативноправових актів у цій сфері. Такий же підхід демонструє і аграрно-правова наука, вивчаючи правове регулювання СФЗ: ці правовідносини досліджуються не комплексно, а побічно - переважно під час дослідження різних інших юридичних питань (наприклад, правової специфіки виробництва м'ясної та молочної продукції, рослинництва, переробки сільськогосподарської продукції тощо).

На відміну від традиційного виробничо-господарського підходу, агропротекиійний концептуальний niдxid в сучасній аграрно-правовій доктрині не є таким розвиненим. Він акцентує увагу на інших особливостях правовідносин застосування СФЗ, а саме: вони мають не лише суто виробничий зміст - вони за певних умов можуть набувати яскраво вираженого агропротекційного характеру, що розкриває ще одну специфічну особливість юридичної природи цих відносин.

Досліджуючи проблематику правового регулювання державної підтримки сільського господарства в Україні, Х. А. Григор'єва довела існування у складі сучасного аграрного права підгалузі агропротекційного права. Учена вважає, що предметом цієї підгалузі виступають агропротекційні відносини - врегульовані правом суспільні відносини, які виникають 3 приводу надання державної підтримки сільському господарству ${ }^{4}$. Тобто, агропротекційні відносини $\epsilon$ невід'ємною складовою аграрного права України, однак вони настільки специфічні, що формують власну відносно відокремлену підсистему. При глибшому аналізі відносин застосування СФЗ у контексті міжнародної торгівлі та зобов'язань перед СОТ і ЄС проявляється досить рельєфна характерна особливість таких відносин - вони активно використовуються для підтримки вітчизняних товаровиробників у їх конкурентній боротьбі із іноземним сільськогосподарським імпортом. Насправді, ці процеси є цілком закономірними.

\footnotetext{
${ }^{1}$ Бугера, С. І. (2011). Якість сільськогосподарської продукції як предмет аграрного права та методи їі правового регулювання. Підприємництво, господарство і право, 10, 83-85.

${ }^{2}$ Купченя, Л. І. (2018). Функції аграрного права в сучасних умовах розвитку України. Пріоритетні напрями розвитку аграрного законодавства і права в сучасних умовах: матеріали конференції ( 20 квітня 2018 р., м. Харків), 201-205.

${ }^{3}$ Статівка, А. М. (2017). Сучасне аграрне право в контексті євроінтеграційних процесів. Сучасний стан та перспективи розвитку екологічного, земельного та аграрного права в умовах євроінтеграції: матеріали круглого столу (8 грудня 2017 р., м. Харків), 94-98.

${ }^{4}$ Григор'єва, Х. А. (2020). Концептуальні засади правового регулювання державної підтримки сільського господарства в Україні: автореферат дисертації на здобуття наукового ступеня доктора юридичних наук. Одеса: НУ «Одеська юридична академія», 3-40.
} 
Аналізуючи агропротекційний потенціал застосування СФЗ, слід вказати на те, що Україна знаходиться у досить вразливому становищі: з одного боку, вона змушена максимально лібералізувати умови імпорту іноземної сільськогосподарської продукції відповідно до ії міжнародних зобов'язань, а з іншого - вона практично позбавлена можливостей застосування СФЗ в ролі легальних нетарифних бар'єрів на шляху стримування потоку іноземних товарів з огляду на порівняну слабкість внутрішніх товаровиробників (слід пам'ятати про те, що підвищення вимог до імпортерів має корелювати із відповідним підвищенням вимог до національних виробників). У зв’язку зцим Україна має використовувати усі доступні дипломатичні та інші важелі впливу для захисту інтересів національних виробників сільськогосподарської продукції, зокрема шляхом застосування СФЗ.

Важлива роль нетарифних обмежень була фактично визнана СОТ шляхом прийняття принципового рішення не заборонити, а врегулювати ці відносини. Велика кількість нетарифних методів та інструментів регулювання, які використовуються багатьма країнами, стала причиною укладання в рамках системи ГАТТ/СОТ угод для регулювання та регламентації їх застосування країнами-членами (зокрема, Угода про застосування санітарних та фітосанітарних заходів, Угода про технічні бар'єри у торгівлі та інші) ${ }^{1}$.

До технічних бар'єрів належать і декілька специфічних сфер - санітарні, ветеринарні та фітосанітарні правила і норми. Технічні бар'єри застосовуються найчастіше - ними регулюється майже 2/3 міжнародної торгівлі. У різних секторах економіки обсяг нетарифних обмежень залежить як від технічних, так і від економічних чинників. Наприклад, деякі товари, зокрема продукція сільського господарства, підпадають під жорстке регулювання з урахуванням принципів захисту прав споживачів, охорони довкілля та технічних стандартів ${ }^{2}$.

Слід окремо вказати на теоретичну та практичну необхідність розмежування СФЗ від суміжної категорії - технічних бар'єрів. Санітарні та фітосанітарні заходи разом із технічними регламентами, стандартами та процедурами оцінки відповідності складають окрему групу обмежень торгівліобмеження, що пов'язані з вимогами до характеристик товарів. I саме мета застосування обмежень виступає головною та єдиною ознакою, яка дозволяє відокремити зазначені вище технічні бар'єри у торгівлі (технічні регламенти, стандарти та процедури оцінки відповідності) від санітарних та фітосанітарних заходів. СФЗ використовуються з метою захисту життя та здоров'я людей, тварин та рослин від ризиків, пов'язаних з продуктами харчування, хвороботворними організмами та шкідниками, а також, з метою попередження інших втрат від шкідників. ТБТ застосовуються для захисту життя та здоров'я людей, тварин та рослин від усіх інших ризиків, а також для досягнення інших цілей (зокрема, з метою захисту навколишнього середовища, підтримки національної безпеки, запобігання шахрайським діям, а також уніфікації товарів). Сутністю СФЗ є будь-які обмеження торгівлі, які запроваджуються для досягнення таких цілей як: захист життя та здоров'я людей від ризиків, пов'язаних із харчовими продуктами, хворобами тварин та рослин, а також шкідниками; захист життя та здоров'я тварин та рослин від ризиків, пов'язаних з кормами, хворобами та шкідниками; - попередження інших втрат від шкідників. У свою чергу, об'єктом СФЗ найчастіше виступають продовольство, тварини, рослини, товари рослинного та тваринного походження, тощо. Вимоги СФЗ $є$ обов'язковими до виконання. Для СФЗ $є$ характерним дотримання принципу послідовності, наприклад, якщо у випадку обмеження державою ввезення певної продукції тваринництва через ризик проникнення на свою територію певного захворювання, має бути обмеженим і ввезення іншої продукції тваринництва, з якою пов'язаний аналогічний ризик. Застосування СФЗ необхідно обгрунтовувати шляхом аналізу ризику спираючись на наукові принципи є дещо жорсткішими, ніж правила застосування заходів технічного регулювання ${ }^{3}$.

Урахування міжнародно-правового контексту надає агропротекційному концептуальному підходу до розуміння аграрно-правової природи відносин застосування СФЗ досить важливого звучання та актуалізує потребу в його активному вивченні. Наразі агропротекційний аспект юридичної природи відносин застосування СФЗ є типовим, але залишається фактично напівлегальним.

\footnotetext{
1 Дем'янюк, О. (2013). Актуальні проблеми нетарифного регулювання зовнішньоекономічної діяльності в Україні. Вісник ТНЕУ,4, 94-102.

2 Дугієнко, Н. О., Акінєєва, Д. О. (2014). Нетарифне регулювання як засіб захисту внутрішнього ринку країн ЄС та України. Інноваційна економіка, 5, 17-21.

${ }^{3}$ Бураковський, І., Кравчука, К., Мовчан, В. (ред.) (2015). Технічні бар'єри та санітарні і фітосанітарні заходи в міжнародній торгівлі: види, тенденції розвитку, регулювання. Посібник державного службовця. Київ: Інститут економічних досліджень і політичних консультацій, 32-97.
} 
Висновки та перспективи подальших досліджень. Юридична природа відносин застосування СФЗ є комплексною та має чотири невід'ємні складові: аграрно-правову, еколого-правову, адміністративно-правову та міжнародно-правову. Існує потреба у дослідженні цих правовідносин саме як єдиного комплексу, цілісної системи, що найбільш повно відображатиме їх об'єктивну сутність. Ця потреба посилюється тенденцією перманентного взаємопроникнення виокремлених складових. Незважаючи на те, що виокремлені складові представляють собою тісно взаємопов'язаний комплекс, вбачається, що можна встановити певну їх внутрішню ієрархію. Так, на наше переконання, базовою є саме аграрно-правова складова відносин застосування СФЗ, оскільки ці правовідносини зароджуються саме внаслідок сільськогосподарської діяльності, з огляду на її антропогенний вплив на природу, для задоволення потреб сільськогосподарських виробників та для захисту від негативних наслідків такого впливу.

Підводячи підсумки, можна зазначити, що міжнародні зобов'язання, взяті Україною перед СОТ та $\mathrm{CC}$, значно модифікують традиційні уявлення про аграрно-правову природу відносин у сфері застосування СФЗ. Ці зміни відбуваються у напрямі розуміння цих правовідносин як єдиного комплексу, що вимагає відповідного системного наукового дослідження та законодавчого регулювання.

\section{References:}

1. Bahay, N. O. (2017). Naukovi pidkhody do periodyzatsiyi rozvytku ahrarnoho zakonodavstva [Scientific approaches to the periodization of agricultural legislation]. Pravovi problemy derzhavno-pryvatnoho partnersta $v$ umovakh yevrointehratsiyi: materialy mizhnarodnoho konhresu (2-4 chervnya 2017 r., m. Odesa) [Legal problems of the public-private partnership in the conditions of European integration: materials of the international congress (June 2-4, 2017, Odessa)], 84-86. [in Ukrainian].

2. Bosnyuk-Hryhoryeva, Yu. (2017). Ukrayina na shlyakhu do yevropeyskykh standartiv u sferi sanitarnykh ta fitosanitarnykh zakhodiv: shcho zrobleno ta yaki vyklyky slid podolaty [Ukraine on the way to European standards in the field of sanitary and phytosanitary measures: what has been done and what challenges need to be overcome]. Istoryko-pravovyy chasopys [Historical and legal journal], 2 (10), 170-175. [in Ukrainian].

3. Buhera, S. I. (2011). Yakist silskohospodarskoyi produktsiyi yak predmet ahrarnoho prava ta metody yiyi pravovoho rehulyuvannya [Quality of agricultural products as a subject of agrarian law and methods of its legal regulation]. Pidpryyemnytstvo, hospodarstvo i pravo [Entrepreneurship, economy and law], 10, 83-85. [in Ukrainian].

4. Burakovskyi, I., Kravchuka, K., Movchan, V. (ed.) (2015). Tekhnichni baryery ta sanitarni i fitosanitarni zakhody $v$ mizhnarodniy torhivli: vydy, tendentsiyi rozvytku, rehulyuvannya. Posibnyk derzhavnoho sluzhbovtsya [Technical barriers and sanitary and phytosanitary measures in international trade: types, development trends, regulation. Civil servant's manual. Kyiv: Institute for Economic Research and Policy Consulting]. Kyiv: Instytut ekonomichnykh doslidzhen i politychnykh konsultatsiy. [in Ukrainian].

5. Hryhoryeva, Kh. A. (2020). Kontseptualni zasady pravovoho rehulyuvannya derzhavnoyi pidtrymky silskoho hospodarstva v Ukrayini [Conceptual bases of legal regulation of the state support of agriculture in Ukraine]: avtoreferat dysertatsiyi na zdobuttya naukovoho stupenya doktora yurydychnykh nauk [abstract of the dissertation on completion of a scientific degree of the doctor of legal sciences]. Odesa: NU Odessa: Odessa Law Academy. [in Ukrainian].

6. Demyanyuk, O. (2013). Aktualni problemy netaryfnoho rehulyuvannya zovnishnoekonomichnoyi diyalnosti $\mathrm{v}$ Ukrayini [Actual problems of non-tariff regulation of foreign economic activity in Ukraine]. Visnyk TNEU [Bulletin of TNEU], 4, 94-102. [in Ukrainian].

7. Duhiyenko, N. O., Akinyeyeva, D. O. (2014). Netaryfne rehulyuvannya yak zasib zakhystu vnutrishnoho rynku krayin YES ta Ukrayiny [Non-tariff regulation as a means of protecting the internal market of the EU and Ukraine]. Innovatsiyna ekonomika [Innovative economy], 5, 17-21. [in Ukrainian].

8. Dukhnevych, A. V. (2016). Pravovi problemy realizatsiyi Uhody pro silske hospodarstvo SOT v Ukrayini [Legal problems of implementation of the WTO Agreement on Agriculture in Ukraine]. Kyiv. [in Ukrainian].

9. Dukhnevych, A. V. (2017). Orhanizatsiyno-pravove zabezpechennya realizatsiyi uhod Svitovoyi orhanizatsiyi torhivli u silskomu hospodarstvi Ukrayiny [Organizational and legal support for the implementation of the World Trade Organization agreements in agriculture of Ukraine]. Kyiv. [in Ukrainian].

10. Dukhnevych, I. V. (2011). Rozvytok ahrarnoho zakonodavstva Ukrayiny [Development of agrarian legislation of Ukraine]. Kyiv. [in Ukrainian].

11. Yermolenko, V. M., Hafurova, O. V., Hrebenyuk, M. V. (2010). Ahrarne pravo Ukrayiny [Agrarian law of Ukraine]. Kyiv. [in Ukrainian].

12. Kovalenko, T. O. (2015). Obyektyvni umovy formuvannya ahrarnoho prava Ukrayiny [Objective conditions for the formation of agrarian law of Ukraine]. Istoryko-pravovyy chasopys [Historical and legal journal], I (5), 80-85. [in Ukrainian]. 
13. Kovalenko, T. O. (2015). Peredumovy formuvannya ahrarnoho prava Ukrayiny [Prerequisites for the formation of agrarian law of Ukraine]. Suchasni tendentsiyi ta perspektyvy rozvytku ahrarnoho, zemel'noho i ekolohichnoho prava: materialy konferentsiyi (22-23 travnya 2015 r., m. Kyiv) [Current trends and prospects for the development of agricultural, land and environmental law: conference proceedings. (May 22-23, 2015, Kyiv)], 44-47.

[in Ukrainian].

14. Korniyenko, H. S. (2018). Ahrarne pravo yak stratehichna haluz prava [Agrarian law as a strategic branch of law]. Priorytetni napryamy rozvytku ahrarnoho zakonodavstva i prava $v$ suchasnykh umovakh: materialy konferentsiyi (20 kvitnya 2018 r., m. Kharkiv) [Priority directions of development of agrarian legislation and law in modern conditions: conference materials (April 20, 2018, Kharkiv)], 77-81. [in Ukrainian].

15. Kupchenya, L. I. (2018). Funktsiyi ahrarnoho prava v suchasnykh umovakh rozvytku Ukrayiny [Functions of agrarian law in modern conditions of development of Ukraine]. Priorytetni napryamy rozvytku ahrarnoho zakonodavstva i prava $v$ suchasnykh umovakh: materialy konferentsiyi (20 kvitnya $2018 \mathrm{r}$., m. Kharkiv) [Priority directions of development of agrarian legislation and law in modern conditions: conference materials (April 20, 2018, Kharkiv)], 201-205. [in Ukrainian].

16. Kurzova, V. V. (2009). Ekoloho-pravove rehulyuvannya karantynu roslyn [Ecological and legal regulation of plant quarantine]: avtoreferat dysertatsiyi na zdobuttya naukovoho stupenya kandydata yurydychnykh nauk [dissertation abstract for the degree of Candidate of Law Science]. Kyiv: NU bioresursiv i pryrodokorystuvannya Ukrayiny. [in Ukrainian].

17. Nosik, V. V. (2010). Ahrarni prava ta yikh yurydychna pryroda v suchasnykh umovakh [Agrarian rights and their legal nature in modern conditions]. Aktualni problemy reformuvannya zemelnykh, ekolohichnykh, ahrarnykh ta hospodarskykh pravovidnosyn $v$ Ukrayini: zbirnyk naukovykh prats naukovo-praktychnoyi konferentsiyi (14-15 travnya 2010 r., m. Khmelnytsky) [Current issues of reforming land, environmental, agricultural and economic relations in Ukraine: a collection of scientific papers of the scientific-practical conference (May 14-15, 2010, Khmelnytsky)], 122-123. [in Ukrainian].

18. Polyukhovych, L. I. (2014). Orhanizatsiyno-pravovi pytannya vyrobnytstva, pererobky ta realizatsiyi silskohospodarskoyi produktsiyi u konteksti vymoh SOT [Organizational and legal issues of production, processing and sale of agricultural products in the context of WTO requirements]: avtoreferat dysertatsiyi na zdobuttya naukovoho stupenya kandydata yurydychnykh nauk [abstract of the dissertation for the degree of candidate of legal sciences]. Kharkiv: NU im. Yaroslava Mudroho. [in Ukrainian].

19. Semchyk, V. I .(2005). Orhanizatsiyno-pravovi problemy vstupu Ukrayiny do SOT i Yevropeyskoho Soyuzu ta uchasti u formuvanni yedynoho ekonomichnoho prostoru [Organizational and legal problems of Ukraine's accession to the WTO and the European Union and participation in the formation of a single economic space]. Pravova derzhava [Constitutional state], 16, 325-334. [in Ukrainian].

20. Stativka, A. M. (2017). Suchasne ahrarne pravo v konteksti yevrointehratsiynykh protsesiv [Modern agrarian law in the context of European integration processes]. Suchasnyy stan ta perspektyvy rozvytku ekolohichnoho, zemelnoho ta ahrarnoho prava v umovakh yevrointehratsiyi: materialy kruhloho stolu (8 hrudnya 2017 r., $m$. Kharkiv) [Current state and prospects of development of ecological, land and agrarian law in the conditions of European integration: materials of the round table (December 8, 2017, Kharkiv)], 94-98. [in Ukrainian].

21. Urkevych, V. Yu. (2997). Ahrarni pravovidnosyny v Ukrayini [Agrarian legal relations in Ukraine]: avtoreferat dysertatsiyi na zdobuttya naukovoho stupenya doktora yurydychnykh nauk [dissertation abstract for the degree of Doctor of Laws]. Kharkiv: Natsionalnyy yurydychnyy universytet im. Yaroslava Mudroho. [in Ukrainian].

22. Chabanenko, M. M. (2015). Systema ahrarnoho prava Ukrayiny: metodolohichni zasady stanovlennya ta rozvytku [The system of agrarian law of Ukraine: methodological principles of formation and development]. Kyiv. [in Ukrainian].

23. Bahay, N. O. (2002). Rozvytok nauky ahrarnoho prava Ukrayiny [Development of the science of agrarian law of Ukraine]: avtoreferat dysertatsiyi na zdobuttya naukovoho stupenya kandydata yurydychnykh nauk [dissertation abstract for the degree of candidate of legal sciences]. Kyiv: Instytut derzhavy i prava imeni V. M. Koretskoho. [in Ukrainian]. 